\title{
Influence of Maternal Renal Infection on the Foetus and Infant
}

\author{
MARGUERITE J. PATRICK \\ From the Department of Paediatrics, Stobhill General Hospital, Glasgow
}

In 1962 Kass drew attention to the increased perinatal mortality and prematurity rate in his series of bacteriuric patients in Boston. In the past decade a not inconsiderable number of similar studies has been made. No uniformity of results has emerged. The clarification of this point, with regard to the aetiology of prematurity in infants born in Stobhill General Hospital, Glasgow, was the starting point of a prospective study on renal tract infection in pregnancy. In this paper foetal and infant loss is assessed, with the hitherto unreported finding that dorsal mid-line fusion defects are significantly more frequent in infants of bacteriuric mothers than of non-bacteriuric mothers. Prematurity rates are assessed and evidence is shown suggestive of transfer of infection from the bacteriuric mother to her child.

\section{Materials and Methods}

Of 133 antenatal patients with coliform bacteriuria of over 100,000 organisms per ml., 75 were known to be infected for periods of from 2 to 28 weeks, with an average of 13 weeks. These patients were still bacteriuric at the 37th week, or at the time of delivery where this occurred earlier. In the remaining 58 mothers bacteriuria was successfully eradicated by prolonged chemotherapy. The urine was sterile by the 37 th week and had been so for periods of from 4 to 22 weeks, with an average of 12 weeks. The first part of this paper deals with the incidence rates of abortions, stillbirths, and neonatal deaths in these two groups of patients and in a control group of $\mathbf{5 0 0}$ mothers with no urinary infection in the antepartum period. Prematurity rates are compared for the three maternal groups in respect of infants weighing $2500 \mathrm{~g}$. and less and of under 37 weeks' gestation, $2500 \mathrm{~g}$. and less and over 37 weeks' gestation, and more than $2500 \mathrm{~g}$. but under 37 weeks' gestation.

The second part of the paper deals with the possibility of transfer of infection from mother to baby. Urine specimens were collected from the babies after careful local washing of the infant with sterile water, thorough

Received July $12,1966$. drying, and the application of a Chironseal bag (Down Bros. and Mayer and Phelps Ltd.). Bacterial counts by the quantitated loop technique (McGeachie and Kennedy, 1963) were carried out by the Bacteriology Department, Stobhill Hospital. Counts of over 100,000 organisms per $\mathrm{ml}$. were regarded as constituting significant infection. Amniotic fluid was obtained by DrewSmythe catheter in 16 cases, by abdominal amniocentesis in 2 , and at the time of spontaneous membrane rupture in 1. Gram-stained smears were prepared and the remaining fluid was cultured. Umbilical cord blood was obtained by needle puncture of the vein and injection into standard blood culture media. Sections of placentae and cords were prepared by the Pathology Department, Stobhill Hospital, by routine methods.

\section{Results}

Foetal and infant loss. Table I shows the numbers of abortions, stillbirths, and neonatal deaths in the three groups of patients: 75 essentially bacteriuric patients, 58 successfully treated patients, and 500 mothers with sterile urine in the antepartum period. It shows that there was no significant difference in the abortion or stillbirth rates of the bacteriuric group of mothers, the successfully treated mothers, and the non-bacteriuric control group. Neonatal deaths, however, were significantly more frequent in both the bacteriuric and treated bacteriuric mothers than in the control group ( $p<0.01$ for both comparisons). There was no significant difference in the number of neonatal deaths amongst the bacteriuric and the successfully treated mothers.

Low birthweight and short gestation babies. Table II illustrates the incidence rates of low birthweight and/or short gestation babies in the same three groups of mothers. Statistical analysis shows that there is no significant difference in incidence rates of babies at a disadvantage in mothers with bacteriuria, with successfully treated bacteriuria, and in non-bacteriuric mothers. Further, by 
TABLE I

Foetal and Infant Loss in 75 Bacteriuric Mothers, 58 Treated (ex-bacteriuric) Mothers, and 500 Non-bacteriuric Mothers

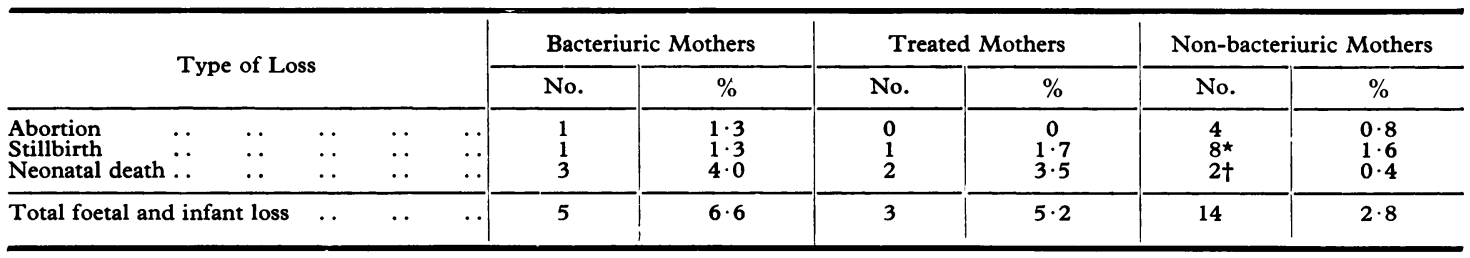

* 3 stillbirths excluded ( 1 hydrops foetalis; 2 post-mature). † 2 neonatal deaths excluded (Rhesus haemolytic disease 2 ).

TABLE II

Incidence of Low Birthweight and Short Gestation Babies in 75 Bacteriuric Mothers, 58 Treated (ex-bacteriuric) Mothers, and 500 Non-bacteriuric Controls

\begin{tabular}{|c|c|c|c|c|c|c|c|}
\hline \multirow[t]{2}{*}{ Birth Group } & & \multicolumn{2}{|c|}{$\begin{array}{c}\text { Infants of Bacteriuric } \\
\text { Mothers }\end{array}$} & \multicolumn{2}{|c|}{$\begin{array}{c}\text { Infants of Treated } \\
\text { Mothers }\end{array}$} & \multicolumn{2}{|c|}{$\begin{array}{c}\text { Infants of Control } \\
\text { Mothers }\end{array}$} \\
\hline & & No. & $\%$ & No. & $\%$ & No. & $\%$ \\
\hline $\begin{array}{l}2500 \mathrm{~g} . \text { and under, and under } 37 \text { weeks } \\
2500 \text { g. and under, and over } 37 \text { weeks } \\
\text { Over } 2500 \text { g., and under } 37 \text { weeks } \quad .\end{array}$ & $\begin{array}{l}\cdots \\
\cdots \\
\cdots\end{array}$ & $\begin{array}{l}2 \\
5 \\
2\end{array}$ & $\begin{array}{l}2 \cdot 7 \\
6 \cdot 7 \\
2 \cdot 7\end{array}$ & $\begin{array}{l}1 \\
3 \\
3\end{array}$ & $\begin{array}{l}1 \cdot 7 \\
5 \cdot 2 \\
5 \cdot 2\end{array}$ & $\begin{array}{r}13 \\
24 \\
8\end{array}$ & $\begin{array}{l}2 \cdot 6 \\
4 \cdot 8 \\
1 \cdot 6\end{array}$ \\
\hline $\begin{array}{lll}\text { Total infants at disadvantage .. } & \ldots\end{array}$ & .. & 9 & $12 \cdot 1$ & 7 & $12 \cdot 1$ & 45 & $9 \cdot 0$ \\
\hline
\end{tabular}

TABLE III

Incidence and Type of Congenital Defect in Infants of 133 Bacteriuric Mothers and 500 Control Mothers

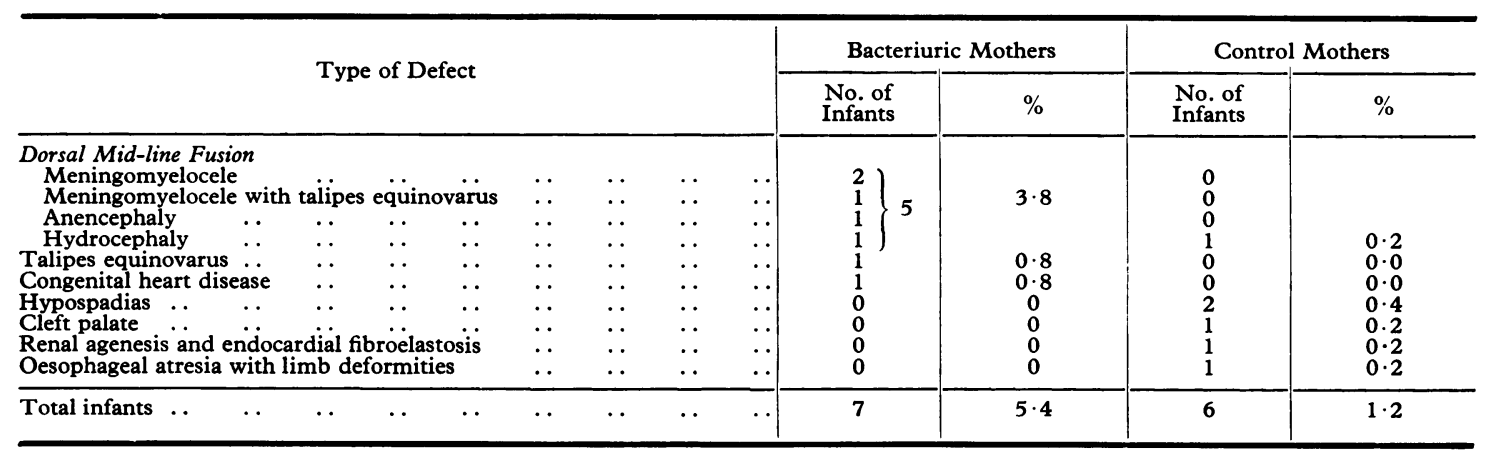

For dorsal mid-line fusion defects separately, and for all defects $\mathrm{p}<0.01$.

lightening the groups by removal of babies of low birthweight associated with pre-eclamptic toxaemia, there is still no significant difference.

Congenital defects. Table III shows an analysis of the type of congenital defect occurring in the infants of 133 bacteriuric mothers and 500 control mothers with no urinary infection in the antepartum period. Since the developmental processes concerned were already complete by the time these patients were first seen, it is reasonable and convenient to consider all the bacteriuric mothers together.

In Table III it is seen that congenital defects were more frequent amongst the infants of bacteriuric than non-bacteriuric mothers, and further, that while the nature of the defect was varied in the latter group, 5 of 7 infants in the former group showed abnormalities of dorsal mid-line fusion. Four defects $(3 \%)$ in the infants of the infected mothers 
Incidence of Significant Coliform Bacteriuria in 41 Infants of Bacteriuric Mothers, 28 Infants of Treated (exbacteriuric) Mothers, and 29 Infants of Non-bacteriuric Mothers

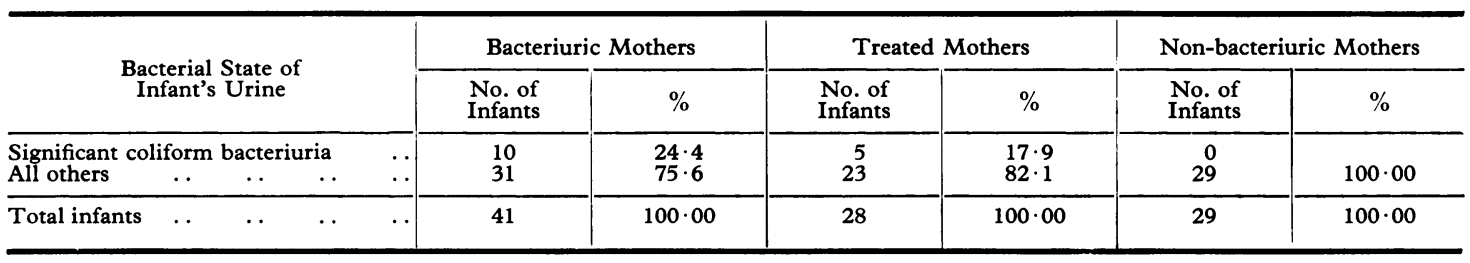

were lethal, compared with $3(0.6 \%)$ in the noninfected mothers $(\mathrm{p}<0.01)$.

\section{Evidence of transfer of infection from mother to baby.}

(i) Neonatal bacteriuria and clinical pyelonephritis. Table IV shows the incidence of significant coliform bacteriuria on at least one occasion in the infants of 41 mothers of the bacteriuric group, 28 mothers of the successfully treated bacteriuric group, and 29 non-bacteriuric mothers. The infants of mothers who were bacteriuric beyond the 37 th week of pregnancy, and those of mothers whose bacteriuria was eradicated by the 37 th week showed a higher rate of significant coliform bacteriuria than did the infants of non-bacteriuric mothers. The difference between the infants of untreated bacteriuric mothers and controls is significant at $p$ value $<0.01$, and between infants of treated bacteriuric mothers and controls at $p$ value between 0.02 and $0 \cdot 01$. There is no significant difference between the infants of treated and untreated bacteriuric mothers, the $p$ value being between $0 \cdot 70$ and 0.50 .

Clinical pyelonephritis was seen in $4(3 \%)$ of the above infants of 133 bacteriuric mothers, and in 1 $(0 \cdot 2 \%)$ of 500 infants of the non-bacteriuric control mothers. 3 of the 4 cases occurred in infants of the 58 mothers whose bacteriuria was eradicated by the 37th week of gestation, and the remaining case occurred in a mother who was bacteriuric at least during the last 12 weeks of pregnancy and into the puerperium.

(ii) Amniotic fluid infection. Eight specimens of amniotic fluid were obtained from mothers who were bacteriuric beyond the 37th week of gestation. In 4 of these specimens coliform bacilli were found on examination of Gram-stained smears. Esch. coli was grown on culture in 3, and in the fourth the receptacle for collection of amniotic fluid was accidentally contaminated with chlorhexidine cream, and no growth occurred. Three specimens of amniotic fluid were obtained from bacteriuric mothers whose urine was sterile by the 37th week of pregnancy, and 8 specimens from non-bacteriuric mothers. They showed no organisms in Gramstained smears, and no growth on culture.

(iii) Umbilical cord blood infection. Umbilical cord blood was cultured from 19 mothers with bacteriuria beyond the 37th week of pregnancy. Six of these produced a growth of Esch. coli, and in 4 of these the growth was described as heavy. Twelve specimens were cultured from mothers whose bacteriuria was eradicated by the 37 th week. Of these, 2 specimens showed a growth of Esch. coli, and both were described as heavy. Twenty specimens of cord blood were obtained from non-bacteriuric mothers and all were sterile.

(iv) Infection in placentae and umbilical cords. 17 placentae and cords were examined for evidence of infection in the form of leucocytic infiltration. 5 of these belonged to the mothers whose bacteriuria persisted after the 37th week of gestation. One cord showed leucocytic infiltration outside the normal limits, and one showed scanty leucocytes not considered to be significant. The remaining specimens were of normal appearance. 12 placentae and cords were obtained from the group of mothers whose bacteriuria was eradicated by the 37 th week. One placenta showed scanty leucocytes in one area only, and one showed an abscess. Three umbilical cords showed areas of haemorrhage, and in one this was accompanied by leucocytic infiltration. The remaining specimens appeared normal. Placentae and cords from 12 non-bacteriuric mothers were examined: 11 showed no abnormality, but in the 12th there were small areas of polymorph infiltration in the placenta. In none of these mothers were the membranes ruptured for more than 8 hours before delivery. Table $\mathrm{V}$ summarizes the results of examination of the above specimens of amniotic fluid, umbilical cord blood, placentae, and cords for infection. 
TABLE V

Result of Examination of Amniotic Fluid, Umbilical Cord Blood, Placentae, and Cords, for Infection

\begin{tabular}{|c|c|c|c|c|c|c|c|c|}
\hline \multirow{2}{*}{\multicolumn{3}{|c|}{ Material Examined }} & \multicolumn{2}{|c|}{ Bacteriuric Mothers } & \multicolumn{2}{|c|}{ Treated Mothers } & \multicolumn{2}{|c|}{ Non-bacteriuric Mothers } \\
\hline & & & + ve & - ve & + ve & - ve & + ve & - ve \\
\hline $\begin{array}{l}\text { Amniotic fluid } \\
\text { Umbilical cord blood } \\
\text { Placentae and cords }\end{array}$ & $\begin{array}{l}\ldots \\
\cdots\end{array}$ & $\begin{array}{l}\cdots \\
\cdots \\
\cdots\end{array}$ & $\begin{array}{l}4 \\
6 \\
1\end{array}$ & $\begin{array}{r}4 \\
13 \\
4\end{array}$ & $\begin{array}{l}0 \\
2 \\
3\end{array}$ & $\begin{array}{r}3 \\
10 \\
9\end{array}$ & $\begin{array}{l}0 \\
0 \\
1\end{array}$ & $\begin{array}{r}8 \\
20 \\
11\end{array}$ \\
\hline
\end{tabular}

\section{Discussion}

Prematurity is taken by most authors to mean infants of $2500 \mathrm{~g}$. or less at birth. Kass (1962) reduced the high rate of $25 \%$ to $10 \%$ by eradication of bacteriuria with prolonged chemotherapy. Henderson, Entwisle, and Tayback (1962) and Kincaid-Smith and Bullen (1965) have confirmed the finding of an increased prematurity rate, but the latter workers were unable to reduce this by eradication of bacteriuria. Neither Kaitz and Hodder (1961), Turck, Goffe, and Petersdorf (1962), Monzon, Armstrong, Pion, Deigh, and Hewitt (1963), Schamadan (1964), Bryant, Windom, Vineyard, and Sanford (1964), nor Hipple and Schulman (1965) have been able to demonstrate an increased prematurity rate. It is probable that prematurity differs in both aetiology and frequency in various parts of the world, and in Glasgow acute renal infection appears to play no significant part, nor was there any evidence of progressive hypertensive renal disease in this group of patients.

Little has been said of renal tract infection as a cause of spontaneous abortion in human beings. Experimentally it has been shown that coliform endotoxin can produce widespread necrosis, and that in pregnant rabbits the placenta is involved (Lansing, 1963). In this study the incidence rate of abortions in bacteriuric patients was no greater than in the non-bacteriuric patients. It is felt, however, that this is not a suitable group for such a study. The assessment of the rate of renal tract infection in a group of aborting women would give a more reliable picture.

In the present study the notable feature is the increased neonatal death rate. Kass (1962) noted an increase in perinatal mortality in his bacteriuric mothers and stated that this was due to such conditions as prematurity and hyaline membrane disease. This pattern was not seen in the author's cases. The increased neonatal death rate was accounted for by infants with defects of dorsal midline fusion. The rate here was $3.8 \%$ in bacteriuric women, whereas Kalter (1963) quotes the highest combined rate, occurring in Dublin, for anencephaly, spina bifida, and hydrocephaly, as $1 \cdot 27 \%$. The incident rate for the three defects together, and when fatal, is quoted in the First Report of the British Perinatal Mortality Survey (Butler and Bonham, 1963) as 3.4 per thousand births. In the author's series of bacteriuric mothers, fatal cases amounted to $3 \%$. Such defects of development occur between the 2nd and 11th weeks of gestation. By careful analysis of twins and sibs, Kalter (1963) has concluded that anencephaly and spina bifida are probably environmental rather than genetic in origin, though it is known that hydrocephaly is sometimes sex-linked. Such defects occurred in the present study before antenatal care was sought, and while one cannot say that these mothers were bacteriuric at this time, one cannot be sure of the reverse, especially in view of Kass's finding (1960) of bacteriuria in the first two months of pregnancy. The defects were not the result of chemotherapy for urinary tract infection. In 1924 Talbot noted that placental damage frequently resulted in foetal malformation, possibly the result of localized hypoxia. Ingalls, Curley, and Prindle (1952) considered that low tissue oxygen in the mother and foetus would produce local stress on rapidly differentiating tissues, and demonstrated that low atmospheric oxygen could produce anencephaly in mice. Further, Vogel (1961) has described the cerebral circulatory abnormalities in human anencephalics and has found areas of haematopoiesis amongst the disorganized tissues, the presence of which he regards as evidence of anoxia. Pleydell (1960) and Record (1961) both considered that anencephaly was most probably caused by an infective agent. It is possible that in anencephaly associated with maternal renal infection the damage is done by the effect of endotoxin on the chorionic villi, or by direct action on the foetal cells themselves. Direct bacterial action is possible but seems less likely. Anencephaly and spina bifida are associated with birth order, possibly with a little increase in first-borns, and a definite increase after the sixthborn (Kalter, 1963); this would be in keeping with the finding in the present study of an increased incidence rate of bacteriuria in the multiparous. mothers. In addition, it is well known that 
anencephaly tends to repeat itself in subsequent pregnancies, as does urinary tract infection. A prospective study looking for maternal bacteriuria, bacteraemia, and circulating endotoxin during the first 8 weeks of pregnancy would be of great interest in this respect, and there is room for much work in the field of experimental teratology.

In 1930, Kobak suggested that foetal bacteraemia, without ill effect, could arise from infection in the maternal blood. Robinson, Krause, Johnston, and Zwicker (1965) described one case of foetal involvement as a result of maternal bacteraemia, and they said 'the placenta was no barrier', and Krafft, Haberman, and Montgomery in 1963 regarded maternal genito-urinary infection 'including vaginitis, cystitis, and/or pyelonephritis' as a possible cause of sepsis in the newborn. Kunin, Zacha, and Paquin (1962) described clustering of urinary infections in families, and it is possible that the common source may have been the mother. On the other hand, Sweet and Wolinsky (1964) described an outbreak of urinary tract and other infections in a premature nursery, stressing the infectious nature of Esch. coli. That intermittent bacteraemia occurs in the course of pyelonephritis is an established fact, and that this can involve the foetal circulation seems quite possible. Coliform organisms appear to have a special predilection for renal tissue, and may either be excreted from here into the amniotic fluid, from which they can reinfect the foetus, or initiate an intrauterine pyelonephritis.

The incidence of asymptomatic urinary tract infections in the newborn is still uncertain. Special considerations regarding bacterial counts appear to be required in newborn infants. It is felt by the author that a high bacterial count in a small infant, unlike that in a pregnant woman, is open to considerable suspicion of contamination. This is so, particularly in boys when the preputial skin cannot be retracted, where there is delay of over an hour between the cleaning of the mucosa and passing of urine, and where the volume of the specimen is small. It is possible that a Gram-stained drop preparation of fresh urine might be invaluable in infants. While most of the urine specimens for this study were collected with the above factors in mind, one must admit that the control group was collected towards the end of the series, and that the technique used may have improved. This is the only doubt as to the reliability of the findings regarding bacteriuria in the babies of this study.

Having found bacteriuria one must consider its significance in the newborn infant. It is possible that significant bacteriuria can exist without the kidneys becoming involved. Thrupp, Cotran, and
Kass (1964) have described an adult with persistent bacteriuria, who came to necropsy for other reasons, and in whom no renal lesion could be made out. It is known that infants can have asymptomatic bacteriuria, and that some of these develop clinical pyelonephritis within weeks or months (Lincoln and Winberg, 1964). Lich, Howerton, Goode, and Davis (1964) have examined 26 normal newborns and found no evidence of vesico-ureteral reflux, but, in 2 infants with infection, reflux was demonstrated. It is known that in dogs infection alone can cause reflux (Schoenberg, Beisswanger, Howard, Klingenmaier, Walter, and Murphy, 1964), and it may be that while many infants with asymptomatic bacteriuria can clear their infection quickly, a smaller number develop vesico-ureteral reflux and thence clinical pyelonephritis.

Stroup (1962) was unable to demonstrate any convincing evidence of amniotic fluid infection in 52 patients from whom specimens were obtained by amniocentesis or by Drew-Smythe catheter. In the author's series the results were felt to be reliable, especially in that Gram-stained smears were positive as well as cultures. Both series are small. The author's cases were selected in that they were known to have renal tract infection, whereas Stroup's group were unselected, and it is possible that amongst them there was little chance of coinciding with maternal bacteraemia.

Emig, Napier, and Brazie (1961) found inflammation in $13.3 \%$ of a series of placentae and umbilical cords. This they associated with membrane rupture of over 12 hours before delivery, and found inflammation of the birth canal in $50 \%$ of these patients. In the author's series none of the patients had membrane-rupture of over 8 hours before delivery, and yet leucocytic infiltration and an abscess was found. Robinson et al. (1965) found a $14 \%$ incidence rate of inflammation of cord and placenta, and in 2 cases they were able to demonstrate bacteria by Gram-staining. In these patients, however, infection was considered to originate in the vagina.

From what has been said it appears that there is a growing feeling that foetal bacteraemia can result from maternal bacteraemia, and that the placenta should be regarded perhaps not so much as a barrier as a transfer system. The results so far suggest that this line of exploration should be extended both in numbers and in design.

\section{Summary}

Abortion, stillbirth, and prematurity rates were not increased in bacteriuric patients, whether or not 
this persisted throughout pregnancy or was eradicated by prolonged chemotherapy, when compared with a group of non-bacteriuric antenatal patients at Stobhill General Hospital, Glasgow.

The neonatal death rate was significantly increased in the bacteriuric mothers as a whole, and this was mainly due to defects of dorsal mid-line fusion.

Asymptomatic bacteriuria and clinical pyelonephritis were significantly more frequent in the infants of bacteriuric mothers as a whole, compared with those of non-bacteriuric mothers.

Evidence of infection, to suggest that maternal bacteraemia can involve the foetus, was found in amniotic fluid, umbilical cord blood, placentae, and cords.

I wish to thank Dr. I. D. Riley for his support throughout this work. I am indebted to Dr. D. McKay Hart for granting access to obstetrical patients, and to Dr. J. Stevenson for the bacterial counts.

\section{REFERENCES}

Bryant, R. E., Windom, R. E., Vineyard, J. P., and Sanford, J. P. (1964). Asymptomatic bacteriuria in pregnancy and its association with prematurity. F. Lab. clin. Med., 63, 224.

Butler, N. R., and Bonham, D. G. (1963). Perinatal Mortality, p. 225. E. \& S. Livingstone, Edinburgh \& London.

Emig, O. R., Napier, J. V., and Brazie, J. V. (1961). Inflammation of the placenta. Obstet. and Gynec., 17, 743.

Henderson, M., Entwisle, G., and Tayback, M. (1962). Bacteriuria and pregnancy outcome: preliminary findings. Amer. F. publ. Hlth, 52, 1887.

Hipple, R. F., and Schulman, H. (1965). Bacteriuria in pregnancy. Obstet. and Gynec., 26, 396.

Ingalls, T. H., Curley, F. J., and Prindle, R. A. (1952). Experimental production of congenital anomalies. New Engl.f. Med., 247, 758.

Kaitz, A. L., and Hodder, E. W. (1961). Bacteriuria and pyelonephritis of pregnancy: a prospective study of 616 pregnant women. ibid., 265, 667 .

Kalter, H. (1963). Congenital malformations of the central nervous system. Amer. F. clin. Nutr., 12, 264.

Kass, E. H. (1960). Bacteriuria and pyelonephritis of pregnancy. Arch. intern. Med., 105, 194.

(1962). Pyelonephritis and bacteriuria: a major problem in preventive medicine. Ann. intern. Med., 56, 46.
Kincaid-Smith, P., and Bullen, M. (1965). Bacteriuria in pregnancy. Lancet, 1, 395.

Kobak, A. J. (1930). Fetal bacteremia: a contribution to the mechanism of intrauterine infection and to the pathogenesis of placentitis. Amer. F. Obstet. Gynec., 19, 299.

Krafft, C. J., Haberman, S., and Montgomery, J. S. (1963). An evaluation of some diagnostic criteria for neonatal bacteremia. Sth. med. F. (Bgham, Ala.), 56, 1309.

Kunin, C. M., Zacha, E., and Paquin, A. J. (1962). Urinary tract infections in school children. New Engl. F. Med., 266, 1287.

Lansing, A. M. (1963). Septic shock. Canad. med. Ass. F., 89, 583.

Lich, R., Howerton, L. W., Goode, L. S., and Davis, L. A. (1964). Ureterovesical junction of the newborn. F. Urol. (Baltimore), 92, 436.

Lincoln, K., and Winberg, J. (1964). Studies of urinary tract infections in infancy and childhood. II. Quantitative estimation of bacteriuria in unselected neonates with special reference to the occurrence of asymptomatic infections. Acta paediat. (Uppsala), 53, 307.

McGeachie, J., and Kennedy, A. C. (1963). Simplified quantitative methods for bacteriuria and pyuria. F. clin. Path., 16, 32

Monzon, O. T., Armstrong, D., Pion, R. J., Deigh, R., and Hewitt, W. L. (1963). Bacteriuria during pregnancy. Amer. $\mathcal{F}$. Obstet. Gynec., 85, 511.

Pleydell, M. J. (1960). Anencephaly and other congenital abnormalities. An epidemiological study in Northamptonshire. Brit. med. F., 1, 309.

Record, R. G. (1961). Anencephalus in Scotland. Brit. F. prev. soc. Med., 15, 93.

Robinson, S. C., Krause, V. W., Johnston, J., and Zwicker, B. (1965). Significance of maternal bacterial infection with respect to infection and disease in the newborn. Obstet. and Gynec., 25, 664.

Schamadan, W. E. (1964). Bacteriuria during pregnancy. Amer. 7. Obstet. Gynec., 89, 10.

Schoenberg, H. W., Beisswanger, P., Howard ,W. J., Klingenmaier, H., Walter, C. F., and Murphy, J. J. (1964). Effect of lower urinary tract infection upon ureteral function. $\mathcal{F}$. Urol. (Baltimore), 92, 107

Stroup, P. E. (1962). Amniotic fluid infection and the intact fetal membrane. Obstet. and Gynec., 19, 736.

Sweet, A. Y., and Wolinsky, E. (1964). An outbreak of urinary tract and other infections due to E. Coli. Pediatrics, 33, 865.

Talbot, J. E. (1924). The placental infarct and its relation to the etiology of deformed babies. Amer. F. Obstet. Gynec., 8, 271.

Thrupp, L. D., Cotran, R. S., and Kass, E. H. (1964). Relationship of bacteriuria in pregnancy to pyelonephritis. 7. Amer. med. Ass., 189, 899.

Turck, M., Goffe, B. S., and Petersdorf, R. G. (1962). Bacteriuria of pregnancy. Relation to socioeconomic factors. New Engl. 7. Med., 266, 857.

Vogel, F. S. (1961). The anatomic character of the vascular anomalies associated with anencephaly. Amer. F. Path., 39, 163. 